http://dx.doi.org/10.18778/1643-0700.16.20

\author{
Iwona KACZMAREK* \\ Ewa ŚMIECH**
}

\title{
PROBLEMATYKA SZADKU I ZIEMI SZADKOWSKIEJ NA ŁAMACH PERIODYKU „NA SIERADZKICH SZLAKACH”
}

Streszczenie. W artykule wskazano zakres tematyczny i chronologiczny publikowanych na łamach czasopisma „Na Sieradzkich Szlakach” prac dotyczących Szadku i ziem historycznego powiatu szadkowskiego. Dokonany przegląd bibliograficzny upoważnia do stwierdzenia, że problematyka tego regionu została dość szeroko i różnorodnie zaprezentowana. W kręgu zainteresowań autorów artykułów znalazły się dzieje miasta, jego rozwój gospodarczy, a także kulturalno-oświatowy na przestrzeni wieków. W osobnych działach czasopisma zamieszczone zostały biografie wybitnych ludzi związanych z ziemią szadkowską oraz opisane zabytki kultury materialnej i duchowej regionu. Zgodnie z turystyczno-krajoznawczym profilem periodyku publikowane artykuły popularyzują wiedzę o regionie i zachęcają jednocześnie do samodzielnego zwiedzenia tej części kraju.

Słowa kluczowe: Szadek, ziemia szadkowska, czasopismo, „Na Sieradzkich Szlakach”.

Periodyk ,Na Sieradzkich Szlakach. Kwartalnik Regionalnej Pracowni Krajoznawczej w Sieradzu" jest czasopismem turystyczno-krajoznawczym wydawanym od 1985 r. Początkowo pismo ukazywało się jako biuletyn Zarządu Wojewódzkiego Polskiego Towarzystwa Turystyczno-Krajoznawczego, obecnie publikowane jest przez Oddział PTTK w Sieradzu. Celem wydawnictwa jest przede wszystkim propagowanie wiedzy o regionie i pobudzanie ruchu krajoznawczego na obszarze ziemi sieradzkiej. Na układ treści kwartalnika składają się stałe działy obejmujące tematy z zakresu historii ziemi sieradzkiej, ochrony zabytków i przyrody, archeologii, etnografii oraz geografii, współczesnych zagadnień społeczno-gospodarczych, a także turystyki i krajoznawstwa. W dziale $Z$ minionych lat zamieszczane są także przedruki publikacji dotyczących regionu ${ }^{1}$. Wśród roczników czasopisma znajdują się również numery monotematyczne

* Iwona Kaczmarek, mgr, Biblioteka Wydziału Nauk Geograficznych, Uniwersytet Łódzki.

** Ewa Śmiech, mgr, Biblioteka Wydziału Nauk Geograficznych, Uniwersytet Łódzki.

${ }^{1}$ Więcej o profilu czasopisma „Na Sieradzkich Szlakach” zob.: E. Andrysiak, Szadek i ziemia szadkowska na łamach czasopisma krajoznawczego „Na sieradzkich szlakach”, „Biuletyn Szadkowski” 2012, t. 12, s. 181-201. 
poświęcone konkretnym faktom historycznym lub jednej miejscowości. Wśród edycji monograficznych na zamówienie władz samorządowych ukazał się numer poświęcony Szadkowi². Na łamach czasopisma, począwszy od $\mathrm{nr} 4$ z 1995 r., w dziale Wydawnictwa - publikacje - recenzje corocznie omawiane są regionalia oraz prezentowane nowości wydawnicze o ziemi sieradzkiej³. W 2015 r. nakładem PTTK w Sieradzu ukazało się wydawnictwo jubileuszowe pt.: Stąd nasz ród 30 lat Na Sieradzkich Szlakach, pod red. Zdzisława Włodarczyka. Księga stanowi antologię tekstów, które publikowane były na łamach czasopisma w ciągu jego istnienia. Całość poprzedzona została rozdziałami autorstwa Andrzeja Ruszkowskiego i Grzegorza Markiewicza nawiązującymi do historii kwartalnika.

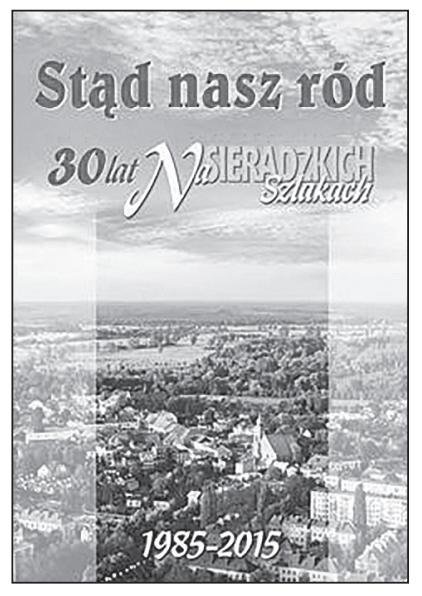

Fot. 1.

Zestawiając bibliografię artykułów poświęconych ziemi szadkowskiej na łamach czasopisma „Na Sieradzkich Szlakach”, wyselekcjonowano teksty dotyczące historii ziem znajdujących się na terytorium dawnego powiatu szadkowskiego oraz omawiające uwarunkowania środowiskowe i społeczno-gospodarcze obszaru dzisiejszej gminy szadkowskiej oraz miasta Szadku. Jako odrębną grupę tematyczną wyszczególniono zamieszczane na łamach czasopisma przedruki publikacji. Bibliografia artykułów dotyczących Szadku i ziemi szadkowskiej podzielona została według stałych działów czasopisma, w których teksty były publikowane, co ułatwia pełną orientację w zawartości prezentowanej na łamach czasopisma tematyki szadkowskiej. Opublikowany w 2012 r. w „Biuletynie Szadkowskim” ar-

2 „Na Sieradzkich Szlakach” 1995, nr 3 (39).

3 T. Dronka, J. Ziarniak, Wydawnictwa o regionie w 1995, „Na Sieradzkich Szlakach” 1995, t. 4, s. $30-32$. 
tykuł Ewy Andrysiak ${ }^{4}$ w sposób szczegółowy omawia sposób prezentacji Szadku i ziemi szadkowskiej na łamach czasopisma „Na Sieradzkich Szlakach” do roku 2010. Z uwagi na to, w niniejszym artykule rok ten stanowi cezurę początkową dla przeprowadzonej analizy tekstów. Zamieszczoną w artykule przedmiotową bibliografię Szadku i ziem dawnego powiatu szadkowskiego udało się nieznacznie poszerzyć o teksty opublikowane na łamach czasopisma „Na Sieradzkich Szlakach" w latach poprzednich oraz uaktualnić. Spis bibliograficzny zestawiony został w obrębie działów w porządku alfabetycznym według nazwisk autorów artykułów.

\section{SZADEK NA ŁAMACH CZASOPISMA „NA SIERADZKICH SZLAKACH”}

W dziale Historia na łamach czasopisma „Na Sieradzkich Szlakach” opublikowanych zostało siedem artykułów poświęconych Szadkowi oraz cztery tematycznie związane z ziemią szadkowską. Przedmiotem zainteresowania autorów były dzieje Szadku, etymologia nazwy miasta i jego herb, a także życie kulturalno-oświatowe miasta na przestrzeni wieków. Najnowszym artykułem poświęconym wydarzeniom z historii miasta jest praca Rafała Bogusławskiego pt. Pożar w Szadku Anno Domini $1696^{5}$. Autor na tle historii pożarów nawiedzających ziemię sieradzką, zwłaszcza w XVII w., ukazuje skutki, jakie nawracający żywioł wywarł na rozwoju gospodarczym Szadku. Miasto płonęło w tym czasie kilkakrotnie: w latach 1629, 1630, 1653, 1665 oraz 1696. Na podstawie zachowanych źródeł historycznych można ustalić straty, jakie Szadek poniósł wskutek pożogi w $1696 \mathrm{r}$. W artykule zacytowana jest treść aktu wniesionego do ksiąg grodzkich i ziemskich sieradzkich w maju 1697 r., dotyczącego pożaru w Szadku, który miał miejsce 11 kwietnia 1696 r. Przechowywany w Archiwum Głównym Akt Dawnych w Warszawie dokument stanowi niezwykle cenne źródło informacji o mieszkańcach Szadku z końca XVII w. Akt zawiera wykaz budynków, które uległy spaleniu oraz wysokość składek na fundusz wspólnotowy ich właścicieli, co wskazuje na stopień zamożności ówczesnych mieszkańców.

Biorąc pod uwagę zawartość treściową publikowanych na łamach periodyku „Na Sieradzkich Szlakach” artykułów, wskazać należy także teksty, które, omawiając szersze zagadnienia, w sposób przyczynkowy informują o Szadku i ziemi szadkowskiej.

\footnotetext{
${ }^{4}$ Problematyka artykułów dotyczących ziemi szadkowskiej, opublikowanych w czasopiśmie „Na Sieradzkich Szlakach” omówiona została w: E. Andrysiak, Szadek i ziemia szadkowska na łamach czasopisma krajoznawczego „,Na Sieradzkich Szlakach”, „Biuletyn Szadkowski” 2012, t. 12, s. $181-201$.

5 R. Bogusławski, Pożar w Szadku Anno Domini 1696”, „Na Sieradzkich Szlakach” 2015, z. 19 (117), s. 12-14.
} 
Najbogatszy w informacje dotyczące historii gospodarczej Szadku i rozwoju rzemiosł na terenie miasta, od średniowiecza do początków XX w., jest artykuł Ryszarda Rosina Zarys dziejów rzemiosła powiatu sieradzkiego ${ }^{6}$. Autor wskazuje, iż Szadek w źródłach historycznych wymieniony jest po raz pierwszy w 1295 r. jako miasto istniejące. Wezwanie zaś kościoła w starym Szadku, którego patronem był św. Idzi, bardzo popularny w Polsce za panowania Władysława Hermana i Bolesława Krzywoustego, pozwala początki pierwotnego osiedla datować na przełom XI/XII w. Szadek, podobnie jak Piotrków Tryb. i Wieluń, należy do miast, które w okresie przejścia od podziału na kasztelanie do podziału na powiaty zajęły miejsce takich starych ośrodków miejskich jak Rozprza, Spicymierz czy Ruda Wieluńska. W 1447 r. w Szadku pojawiają cechy stolarzy, kupców, krawców, tkaczy i szewców, w 1578 r. - kuśnierzy, a w roku 1618 - garncarzy. W XVI w. pracował w Szadku złotnik imieniem Mikołaj. Autor artykułu zaznacza, że Szadek i Warta posiadały, przynajmniej od XIV w., młyny, a w XVXVI w. także niezbędne do wykańczania sukna zakłady, jak folusze i postrzygalnie. Szadek, po Brzezinach, był największym ośrodkiem średniowiecznego sukiennictwa na terenie dzisiejszego województwa łódzkiego. Liczba mistrzów trudniących się tym rzemiosłem dochodziła na przełomie XVI/XVII w. do około 90, co na ówczesne stosunki było znaczną liczbą. W 1616 r. Szadek oprócz 90 sukienników miał 18 kuśnierzy, ponadto 12 krawców i 24 innych rzemieślników. Do XVII w. dużą rolę w gospodarce miejskiej odgrywało warzenie gorzałki i piwa. W tym celu założono w Warcie i Szadku wodociągi. Według przywileju nadanego dla Szadku w 1541 r. główny wodozbiór znajdował się na rynku, skąd wodę rozprowadzano podziemnymi rurami do warzelni, mieszkań i studzien. Najlepszy okres rozkwitu rzemiosła na tym terenie, jak i w całej Polsce, datuje się od XV do XVI wieku. W wykazie podatkowym z roku 1563 r. Szadek został jednak pominięty, a to ze względu na straty, jakie miasto odniosło w wyniku pożaru. Oprócz cechów na terenie miasta działały także bractwa religijne i literackie. Formą organizacji kościelnej były bractwa religijne ubogich, do których należały osoby opiekujące się biednymi. Literaci zwani także literakami znajdowali się w Sieradzu, Szadku i Warcie już w XVI-XVII w. Rozwój gospodarki folwarczno-pańszczyźnianej - jak wskazuje R. Rosin - pozbawił rzemieślników szerokich mas odbiorców, jakimi było chłopstwo, także kolejne wojny, najazd szwedzki w 1655-1656 i wojna północna w początku XVIII w., spowodowały upadek miast. Kryzys dotknął także Szadku. Mieszczanie mieli obowiązek dostarczać żołnierzy i wozy na wyprawy wojenne. W 1655 r. Sieradz i Szadek dawały po jednym pieszym z 35 dymów, a inne miasta z 50. Poprawa nastąpiła dopiero w drugiej połowie XVIII w., ale daleka od dawnej świetności. Autor artykułu wskazuje, że przeciętnie w miastach województwa sieradzkiego osiągnięto wtedy

${ }^{6}$ R. Rosin, Zarys dziejów rzemiosła powiatu sieradzkiego, „Na Sieradzkich Szlakach” 2012, nr 1 (105), s. 35-42. 
$50 \%$ poziomu z XVI i początku XVII w. Według wykazu z 1791 r. w Szadku było 39 rzemieślników reprezentujących 11 zawodów, w tym 8 piekarzy, 7 krawców oraz 6 rzeźników i garbarzy. Według danych statystycznych dla Szadku z 1868 r., na które powołał się R. Rosin, w mieście było 25 bednarzy, 20 szewców, 13 krawców, 14 rzeźników, 9 garncarzy, po 6 stolarzy i piekarzy, po 5 młynarzy i ślusarzy, 4 kołodziejów, 2 farbiarzy i rymarzy, 1 mechanik, 1 kowal i 1 kotlarz, razem - 114 rzemieślników. Przytoczone liczby wskazują, że najwięcej osób w mieście trudniło się zawodami o charakterze spożywczo-odzieżowym, przy czym na pierwsze miejsce wybijało się szewstwo. Na zajęcia związane z obróbką metali przypadał zazwyczaj jeden rzemieślnik. Zastanawiająca jest też, zdaniem R. Rosina, mała ilość murarzy. Jak wskazuje autor artykułu, niektóre miasta posiadały swoją specjalność. Szadek słynął z bednarstwa i garncarstwa. Nauka początkowa u bednarzy w Szadku trwała 3, później 4 lata. Mistrzowie opłacali wpisowe zarówno za uczniów, jak i za czeladników. Przy wyzwolinach sprawiano terminatorowi surdut, spodnie sukienne, westkę czyli kamizelkę, koszulę, buty i czapkę. W razie porzucenia nauki, rodzice ucznia mieli obowiązek sprowadzić go z powrotem lub wynagrodzić straty. Życie cechowe w XIX w. zorganizowane było na podstawie ustawy z $1816 \mathrm{r}$. uzupełnianej następnie rozporządzeniami. Przepisy te utrzymały się do lat 30-tych XX w. Zachowały się protokoły 1927 r. wyzwolin na mistrzów rzeźniczych w Szadku według ukazu cara Aleksandra I. W okresie międzywojennym zmiany $\mathrm{w}$ życiu organizacyjno-prawnym rzemiosła nastąpiły dopiero po wydaniu ustawy z 10 kwietnia 1934 r., według której każdy cech powinien przedstawić władzom powiatowym nowy projekt statutu do zatwierdzenia. Zachowało się pismo starosty sieradzkiego z 1937 r. likwidujące cechy w Szadku $\mathrm{z}$ uwagi na niedopełnienie tejże formalności. Z powodu małej liczby rzemieślników, na miejsce starych cechów zaproponowano zorganizowanie tylko dwóch zbiorowych, jednego dla chrześcijan, drugiego dla niechrześcijan. Wywodząca się ze średniowiecza segregacja wyznaniowa, jak wskazuje R. Rosin, na ogół odbijała się niekorzystnie na rozwoju danego rzemiosła, część rzemieślników bowiem pozostawała poza organizacją zawodową. Dlatego podział taki nie zawsze był stosowany, np. cech fryzjerów w Sieradzu obejmował zarówno chrześcijan, jak i niechrześcijan. $O$ trudnej sytuacji materialnej rzemieślników, w tym czasie, świadczyło niepłacenie składek, mimo że niektóre z nich były bardzo niskie, np. dla rzeźników w Szadku wynosiły 25 gr miesięcznie. W protokołach wszystkich cechów utrwalone są narzekania oraz projekty środków, które miały zaradzić trudnościom finansowym. Także w drukowanych formularzach umów z uczniami rubryka dotycząca wynagradzania nigdy nie była wypełniana. W Szadku, jako wynagrodzenie, mistrzowie otrzymywali bardzo często po 4 korce ziemniaków i 2 żyta, co świadczy o wiejskim pochodzeniu uczniów. Przyrost ludności w miastach sieradzkich był mały, na ogół wynosił ok. $100 \%$ od początku XIX w. do lat 80-tych XX w.

Przyczynki do dziejów rozwoju zawodów prawniczych i medycznych w Szadku odnaleźć można w dwóch artykułach autorstwa Elżbiety Nejman. 
W artykule pt. Pierwsi notariusze nowoczesnej administracji w Sieradzkiem ${ }^{7}$ autorka dostarcza interesujących informacji na temat notariatu szadkowskiego. Na mocy Ustawy rządowej z 4 lipca 1808 r. i reskryptu Ministra Sprawiedliwości z 23 maja 1808 r., w kwestii regulacji funkcjonowania notariuszy, każdy powiat posiadał własną kancelarię notarialną. Działały kancelarie w Sieradzu, Szadku, Warcie i Wieluniu, a także w Kaliszu i od 1810 r. w Zgierzu. Notariusze szadkowscy początkowo obsługiwali powiat obejmujący teren od Uniejowa po Pabianice, pomiędzy rzekami Wartą i Nerem. W latach 1828-1836, w czasach masowego napływu imigrantów do rozwijających się miast, działało w Szadku jednocześnie dwóch rejentów. Szczególnie dużo aktów notarialnych sporządzanych było dla rozrastających się Pabianic. Od 1841 r. teren ten przejął notariat w Łodzi, a następnie, od 1900 r., notariat w samych Pabianicach. W 1895 r. działać zaczął notariat w Zduńskiej Woli. W Szadku kolejno urzędowali Józef Dydyński w latach 1809-1817, Wincenty Kobyłecki 1818-1847, Kajetan Prawdzic Szczawiński 1828-1847, Adam Łukaszewicz 1846-1851, Celestyn Stokowski 1847-1853, Franciszek Miłkowski 1852-1854, Józef Sikorski 1854-1876, Józef Zborowski 1857-1868 i Paweł Styczyński 1869-1875. Ostatnim rejentem w Szadku, do roku 1897, był Jan Kuczyński, po czym tamtejszy notariat został zlikwidowany. Spośród urzędujących w Szadku notariuszy autorka artykułu podaje noty bibliograficzne: Józefa z Dydynia Gozdawy Dydyńskiego, pierwszego rejenta szadkowskiego w latach 1809-1817, Wincentego Kobyleckiego (1818-1836) oraz Kajetana Szczawińskiego (1828-1847).

W artykule poświęconym lekarzom powiatu sieradzkiego ${ }^{8}$, autorka wymienia lekarzy miejskich praktykujących w Szadku: Abrahama Feliksa (1818-1828), Franciszka Deybela (1828-1838), Józefa Kiedrowskiego (1835-1842), Aleksandra Zimermanna (1843-), Konstantego Szeligowskiego (1848-), Jana Gronau, Ignacego Kaczkowskiego, Hipolita Jakubowskiego, Jana Lipińskiego (1902-), Roberta Sallinga oraz Joachima Kowalskiego.

Autorzy publikujący na łamach czasopisma „Na Sieradzkich Szlakach” gros artykułów poświęcili wynikom swych dociekań genealogicznych i ustaleniom danych biograficznych ludzi związanych z Szadkiem. Spośród najnowszych artykułów przybliżających życie i działalność wybitnych szadkowian wymienić można artykuł Józefa Szubzda pt. Ksiądz Ignacy Woszczalski (1832-1899) rodem z Szadku, proboszcz w Chartupi Małej i Choczu9. Staraniem ks. Ignacego Woszczalskiego przeprowadzone zostały prace remontowo-budowlane budynków parafialnych i samego

${ }^{7}$ E. Nejman, Pierwsi notariusze nowoczesnej administracji w Sieradzkiem, „Na Sieradzkich Szlakach" 2012, nr 1 (105), s. 8-15.

${ }^{8}$ E. Nejman, Lekarze powiatu sieradzkiego w XIX wieku, „Na Sieradzkich Szlakach” 2014, nr 2 (114), s. 23-27.

9 J. Szubzda, Ksiadz Ignacy Woszczalski (1832-1899) rodem z Szadku, proboszcz w Charlupi Małej i Choczu, „Na Sieradzkich Szlakach” 2015, nr 1 (117), s. 38-39. 
kościoła w Charłupi Małej. Autor artykułu zamieścił dokładny wykaz inwestycji oraz wykonanych prac konserwatorskich przeprowadzonych z inicjatywy księdza w latach 1864-1879. Z czasem proboszcz zaczął zabiegać o budowę nowej świątyni, kładąc podwaliny pod podjęte przez jego następców dzieło budowy sanktuarium Księżnej Sieradzkiej. Życie i posługa duszpasterska ks. Ignacego Woszczalskiego przypadała na trudny okres po powstaniu styczniowym. Duchowny, jak wskazuje autor artykułu, dawał dowody swej postawy patriotycznej oraz czynnej obrony polskości zagrożonej rusyfikacyjną polityką caratu. Dobitny wyraz dał temu, chroniąc w murach kościoła symbole narodowe - dwa haftowane złote orły z czapraka Józefa Walewskiego, umieszczone na tle obrazu Matki Boskiej Charłupskiej. W 1880 r. ksiądz został przeniesiony do Chocza koło Kalisza, gdzie zmarł w 1899 r.

Postać kolejnego cenionego szadkowianina, Jana Franckiego, przypomniana została w numerze 4 z 2014 r. kwartalnika. Do treści pożegnania leśniczego Leśnictwa Piaski w Nadleśnictwie Szadek, pióra Ludwika Makulskiego, zamieszczonego pierwotnie na łamach „Ziemi Sieradzkiej” (nr 32, 1930 r.), dotarł Jarosław Stulczewski ${ }^{10}$. Przedwcześnie zmarły, w wieku 31 lat, Jan Francki był znanym lokalnym działaczem społecznym - od 1926 r. członkiem Zarządu Towarzystwa Gimnastycznego „Sokół” w Szadku, a od roku 1932 prezesem Koła Związku Rezerwistów w Szadku. J. Francki był uczestnikiem walk 1918 r. w Sieradzu i na Śląsku Cieszyńskim, a także wojny polsko-bolszewickiej. Oddany swej pracy z poświęceniem wypełniał obowiązki służbowe, czego m.in. tragiczną konsekwencją były choroba i śmierć. Pochowany został na cmentarzu w Sieradzu.

Materialnym świadectwem ofiarności rodziny Wierzbowskich jest jeden z zabytków Szadku - kościół farny. Szczegółowych informacji na temat fundacji tejże rodziny na rzecz kościoła dostarcza artykuł Marty Cicheckiej ${ }^{11}$ opublikowany w 2014 r. w stałym dziale czasopisma poświęconym Zabytkom. Na miejscu spalonego w 1331 r. przez Krzyżaków pierwotnego kościoła pod wezwaniem Wniebowzięcia NMP i św. Jakuba około 1335 r. w Szadku stanęła nowa świątynia konsekrowana przez arcybiskupa Janisława. Autorka artykułu nakreśliła krótką historię zmian architektonicznych i wyposażenia wnętrza tego jednego z najstarszych w regionie kościołów. Najbardziej dynamiczne zmiany w historii budowli, jak wskazuje M. Cichecka, przyniósł wiek XVII, kiedy to na plan pierwszy wśród fundatorów wystroju świątyni wysunęła się rodzina Wierzbowskich herbu Jastrzębiec. Kościół farny w Szadku powstał z fundacji nie prywatnej, lecz królewskiej. Wierzbowscy przez szereg lat kolejno zajmowali stanowisko starosty w Szadku. Zdarzało się, że starosta miasta jako urzędnik królewski poczuwał się do dbania o dobro kościoła, fundując ołtarze do jego wnętrza, a tym samym potwierdzając i umacniając swoją pozycję. Taki charakter miały fundacje rodziny Wierzbowskich.

10 J. Stulczewski, Przerwana miłość do lasu. Przedwczesna śmierć Jana Franckiego - leśniczego Leśnictwa Piaski w Nadleśnictwie Szadek, „Na Sieradzkich Szlakach” 2014, nr 4 (105), s. 81.

${ }^{11}$ M. Cichecka, Fundacje rodziny Wierzbowskich na rzecz kościoła farnego w Szadku, „Na Sieradzkich Szlakach" 2014, nr 1 (113), s. 20-22. 
Dominujący w XIX-wiecznym krajobrazie miasta kościół pw. Wniebowzięcia NMP i św. Jakuba Apostoła w Szadku stał się przedmiotem zainteresowania anonimowego korespondenta czasopisma „Przyjaciel Ludu” wydawanego do 1849 r. Przedruk tego ciekawego reportażu zatytułowanego Ułamek z podróży małowniczej po Wietkiej-Polsce. (Wyjątek z listu.) Szadek, poprzedzony wnikliwym wstępem autorstwa Zdzisława Włodarczyka, dotyczącym historii i profilu czasopisma „Przyjaciel Ludu”, zamieszczony został w dziale $Z$ minionych lat przedruki w 2012 r. ${ }^{12}$ Bryła stojącego na wzgórzu kościoła w 1838 r. przedstawiała się następująco: z jednej strony budowli ściany wysokie, okna wąskie, długie, u góry w półokrąg sklepione. Druga strona budowli, która ucierpiała w skutek zniszczenia pożarem, pokryta była niskim gontowym dachem. Mimo kilkakrotnie trawiących kościół pożarów, świątynia zachowała swe gotyckie sklepienie, wsparte na murowanych słupach. Nad wejściem wmurowana była, niestety nieczytelna, tablica kamienna z datą wzniesienia kościoła. Wewnątrz pośrodku znajdowała się umieszczona przy słupie, wyciosana z drzewa ambona, jakby w koronkę opleciona $w$ ozdoby, cała dębowa, złożona z wąkich tafli, na każdej z tychíe, postacie świętych apostołów ${ }^{13}$. Ołtarz z czarnego marmuru, ufundowany przez Wierzbińskich, stanowił zarazem grobowiec rodzinny, przed ołtarzem znajdował się kamień z inskrypcjami rodziny. Na prawo od ołtarza, na ścianie zawieszone były namalowane na blasze portrety dwóch Tarnowskich, w otoczeniu herbów rodzin, z którymi byli spokrewnieni. W kościele znajdowały się szczątki ogromnych kiedyś organów oraz porozrzucane obrazy, które, w ocenie zwiedzającego świątynię, nosiły cechy wskazujące na bizantyńską szkołę malarstwa sakralnego. Pod chórem przedstawiona była postać klęczącego świętego w mniszym ubiorze, z datą 1557 rok, stanowiąca najprawdopodobniej pozostałość jakiegoś większego malowidła.

Oprócz opisu świątyni w reportażu utrwalone zostały scenki rodzajowe charakterystyczne dla ówczesnego Szadku, z targu, karczmy oraz przedstawiające drobny handel żydowski.

\section{HISTORYCZNY POWIAT SZADKOWSKI NA ŁAMACH CZASOPISMA „NA SIERADZKICH SZLAKACH”}

W skład powstałego w XVI w. powiatu szadkowskiego wchodziło osiem miast: Łask, Widawa, Lutomiersk, Szadek, Szczerców, Pabianice, Uniejów i Niemysłów wraz z okolicami. U schyłku XVIII w. granice powiatu wyznacza-

12 Z. Włodarczyk, Szadek w leszczyńskim „Przyjacielu Ludu”, „Na Sieradzkich Szlakach” 2012, nr 1 (105), s. 47-49.

13 Tamże, s. 50. 
ły rzeki Warta, Widawka i Ner, a w skład powiatu wchodziło 39 parafii: z dekanatu uniejowskiego: Brodnia, Chwalborzyce, Drubin, Glinno, Grodzisko, Niemysłów, Niewiesz, Pęczniew, Siedlątków, Świnice, Uniejów, Wartkowice, Wilamów, Wielenin, z dekanatu szadkowskiego: Borszewice, Buczek, Grabno, Korczew, Łask, Marzenin, Restarzew, Sędziejowice, Szadek, Strońsko, Wygiezłów, Zduńska Wola oraz z dekanatu lutomierskiego: Bałdrzychów, Dobroń, Górka, Kwiatkowice, Lutomiersk, Małyń, Męka, Mikołajewice, Pabianice, Rossoszyca, Wierzchy i Zadzim ${ }^{14}$. W wyniku II rozbioru Polski ziemie te dostały się pod panowanie Prus, Szadek został siedzibą pruskiego landrata, a w czasie krótkotrwałego istnienia Księstwa Warszawskiego, polskiego podprefekta. W trakcie zmian administracyjnych granice powiatu zostały zmienione i w XIX w. do powiatu szadkowskiego przynależały miasta Lutomiersk, Łask, Pabianice z okolicami ${ }^{15}$. W opracowanym w ramach niniejszego artykułu spisie bibliograficznym uwzględnione zostały artykuły odnoszące się do historii miejscowości wchodzących w skład historycznego powiatu szadkowskiego do XIX w. Wiele spośród tych miejscowości czeka jeszcze na popularyzację swych dziejów, zabytków i walorów krajoznawczych.

Jako jeden z nielicznych zabytków ziemi dawnego powiatu szadkowskiego, zaprezentowanych na łamach czasopisma „Na Sieradzkich Szlakach” jest kościół w Mikołajewicach p.w. Narodzenia NMP oraz świętych Piotra i Pawła wzniesiony na początku XVIII w. Właśnie temu zabytkowi sporo uwagi poświęca autor artykułu pt. Dworek w Mikołajewicach koło Lutomierska na przełomie XVII i XVIII w., Rafał Bogusławski. Kościół jest drewniany, o konstrukcji zrębowej, z dwuspadowym dachem, oszalowany, trójnawowy z wielobocznym prezbiterium. Na osi fasady wybudowano wieżę na planie kwadratu. W południowej części budynku jest murowana, neogotycka kaplica Najświętszego Serca Jezusowego. Kościół wzniesiony został dzięki fundacji małżonków Dąbków w 1880 r. Ołtarz główny z obrazem Matki Boskiej (wzorowanym na wizerunku Matki Boskiej Częstochowskiej) oraz z rzeźbami Apostołów św. Piotra i św. Pawła pochodzi z początków XVIII w. Obok kościoła znajduje się kamienny monument z wyrytymi kolejnych księży, proboszczów parafii mikołajewskiej, w latach 1775-1967. Spis został przez autora przytoczony w całości.

Artykuł R. Bogusławskiego poświęcony jest zasadniczo nieistniejącemu już dworkowi w Mikołajewicach, którego opis autor odnalazł w księgach grodzkich

${ }^{14}$ E. Nejman, Parafie dekanatu szadkowskiego i niektóre z dekanatu lutomierskiego (powiat szadkowski) w dawnej statystyce, „Biuletyn Szadkowski” 2010, t. 10, s. 245.

${ }_{15}$ Nowe odmiany w geografii zaszłe od $r .1806$ aż do 1811 z krótkim opisem Księstwa Warszawskiego, Wrocław 1811, s. 73, http://www.dbc.wroc.pl/dlibra/doccontent?id=4969\&di rids $=1$ 
sieradzkich. Doniesienie o dworku stanowi część dokumentu spisanego przez Elżbietę ze Zdzychowskich Chodakowską w 1700 r. W spisie inwentarzowym swej dziedzicznej części w Mikołajewicach, zwanej Biesiekierszczyzną, oddanej w dzierżawę Aleksandrowi Modrzewskiemu, E. Chodakowska wymieniła, oprócz dworu, także inne budynki należące do folwarku oraz osiadłość (zabudowania) w tej części wsi. Analizując dokument, autor artykułu stwierdza, iż dwór, budynki gospodarcze i pola uprawne składające się na majątek Chodakowskich w Mikołajewicach były nader skromne. Dworek w zasadzie nie różnił się od chałupy chłopskiej. Na podstawie inwentarzy dóbr ziemskich z przełomu XVII i XVIII w. zachowanych w księgach grodzkich oraz materiałów opublikowanych we współczesnej literaturze tematu, zdaniem R. Bogusławskiego, dojść można do wniosku, że małe dworki kryte snopkami były dość typowym elementem krajobrazu kulturowego tamtejszej Polski. Dodatkową wartością omawianego artykułu jest zamieszczone przez autora drzewo genealogiczne rodziny Chodakowskich herbu Dołęga, od 1540 do początków XIX w.

\section{ZAKOŃCZENIE}

Analizując problematykę artykułów dotyczących ziemi szadkowskiej na łamach czasopisma „Na Sieradzkich Szlakach”, stwierdzić można, że jest ona dość bogato reprezentowana i różnorodna. Podejmowane są tematy gospodarcze, demograficzne, a także omawiające uwarunkowania fizjograficzne miasta. Wiele artykułów przedstawia ważniejsze wydarzenia z dziejów Szadku, przybliża postacie wybitnych szadkowian oraz prezentuje zabytki historii pozostałe w strukturze miasta. Pierwsze artykuły dotyczące Szadku pojawiły się w periodyku w 1991 r. W numerze 1 z 1991 r. Andrzej Ruszkowski, w dziale Poznajemy własny region, zamieścił swój artykuł pt. Szadek - jedno z najstarszych miast Polski (publikowany wcześniej w czasopiśmie „Nad Wartą” 1983, nr 1). Oprócz egzemplarza wydanego w 1995 r., w całości poświęconego Szadkowi, artykuły tematycznie związane z ziemią szadkowską odnaleźć można w 24 numerach czasopisma „Na Sieradzkich Szlakach”, także w najnowszych. Zgodnie z turystyczno-krajoznawczym profilem periodyku, o charakterze regionalnym, głównym celem publikowanych prac jest popularyzacja regionu, szerzenie wiedzy o przyrodzie, kulturze materialnej i duchowej małej ojczyzny, a także zachęcanie do podjęcia samodzielnych eksploracji swego środowiska lokalnego, co przyczynia się do zachowania rodzimych odrębności i przywiązania do ziemi ojczystej. 


\begin{tabular}{|c|c|c|c|}
\hline \multicolumn{4}{|c|}{$\begin{array}{c}\text { ZIEMIA SZADKOWSKA W CZASOPIŚMIE „NA SIERADZKICH SZLAKACH” } \\
\text { - SPIS BIBLIOGRAFICZNY }\end{array}$} \\
\hline \multicolumn{4}{|c|}{ Historia } \\
\hline Autor & Rok & Tytul & Numer, strony \\
\hline Bogusławski R. & 2015 & Pożar w Szadku Anno Domini 1696 & $1(117)$, s. $12-14$. \\
\hline Bogusławski R. & 2012 & $\begin{array}{l}\text { Dworek w Mikotajewicach koto } \\
\text { Lutomierska na przetomie XVII i XVIII w. }\end{array}$ & 1 (105), s. 16-19, il. \\
\hline Dronka T. & 1995 & $\begin{array}{l}\text { Księga pamiątkowa Towarzystwa } \\
\text { Gimnastycznego „Sokót” w Szadku } 1929 \text { r. }\end{array}$ & 3 (39), s. 16, il. \\
\hline Filipczak-Kocur A. & 1991 & $\begin{array}{l}\text { Zjazdy szlachty sieradzkiej za panowania } \\
\text { Wazów } 1578-1668\end{array}$ & nr 1 (21), s. 21-24. \\
\hline Majdański J. & 1995 & Nazwa i herb Szadku & 3 (39), s.17, il. \\
\hline Nejman E. & 2012 & $\begin{array}{l}\text { Pierwsi notariusze nowoczesnej } \\
\text { administracji w Sieradzkiem }\end{array}$ & $1(105)$, s. $8-15$, il. \\
\hline Nogala J. & 1993 & Związek Strzelecki w Boczkach & $2(30)$, s. 6. \\
\hline Puś W. & 1995 & Dzieje Szadku do poczatku XVI w. & $3(39)$, s. $1-4$. \\
\hline Tomaszewicz A. & 1995 & $\begin{array}{l}\text { Obrazki z życia kulturalno-oświatowego } \\
\text { Szadku w XIX i XX w. (do } 1939 \text { r.) }\end{array}$ & 3 (39), s. $13-15$, il. \\
\hline Tomaszewicz A. & 1995 & $\begin{array}{l}\text { Ziemia szadkowska na drodze } \\
\text { do niepodległości 1914-1920 }\end{array}$ & $3(39)$, s. $10-12$, il. \\
\hline Wisińska-Kluba M. & 1995 & Szadek $w$ XVI-XVIII $w$. & $3(39)$, s. 5-9, il. \\
\hline Bogusławski R. & 2008 & $\begin{array}{l}\text { Tajemniczy portret - przyczynek } \\
\text { do biografii Franciszka Budzisz- } \\
\text {-Pstrokońskiego, starosty Szadkowskiego... }\end{array}$ & $1(89)$, s. 16-20, il. \\
\hline Cichecka M. & 2014 & $\begin{array}{l}\text { Fundacje rodziny Wierzbowskich na rzecz } \\
\text { kościoła farnego w Szadku }\end{array}$ & 1 (113), s. 20-22. \\
\hline Dąbrowski D. & 1995 & $\begin{array}{l}\text { Śladami operacji łódzkiej } 1914 \text { r. } \\
\text { po okolicy Szadku }\end{array}$ & 3 (39), s. 18-21, il. \\
\hline Dronka $\mathrm{T}$. & 1995 & Synagoga w Szadku & 3 (39), s. 21 , il. \\
\hline Jaworska A. & 2005 & $\begin{array}{l}\text { Dwór w Woli Przatowskiej-historia } \\
\text { i zagospodarowanie }\end{array}$ & $1(77)$, s. $14-17$, il. \\
\hline Ruszkowski A. & 1991 & Wiatraki & $1(21)$, s. 5-10, il. \\
\hline Jędras M. & 1995 & Józef Leopold z Rzepiszewa & 3 (39), s. 22-23, il. \\
\hline Leopold A. & 2001 & $\begin{array}{l}\text { Krótki opis osiedlenia Leopoldów } \\
\text { w Polsce. Wstęp A. Ruszkowski }\end{array}$ & $2(62)$, s. 24. \\
\hline Ruszkowski A. & 1999 & Alfons Parczewski (1849-1933) & $2(54)$, s. 12. \\
\hline Ruszkowski A. & 1998 & $\begin{array}{l}\text { Marceli Nencki (1847-1901), pionier } \\
\text { biochemii z Boczek pod Sieradzem }\end{array}$ & 4 (52), s. 36-39, il. \\
\hline Sowa P. & 1995 & Dr Ignacy Lipiński [z Szadku] & $3(39)$, s. 23. \\
\hline Szubzda J. & 2015 & $\begin{array}{l}\text { Ksiadz Ignacy Woszczalski (1832-1899) } \\
\text { rodem z Szadku, proboszcz w Chartupi } \\
\text { Matej i Choczu }\end{array}$ & 1 (117), s. 38-39, il. \\
\hline
\end{tabular}




\begin{tabular}{|c|c|c|c|}
\hline Autor & Rok & Tytul & Numer, strony \\
\hline Wisińska-Kluba M. & 1995 & Stawni ludzie regionu & 1-2 (37-38), s. 25-29, il. \\
\hline $\begin{array}{l}\text { Gałczyńska M., } \\
\text { Rudecka H. }\end{array}$ & 2000 & Prusinowice - dzieje wioski i szkoty & $4(60)$, s. $15-18$, il. \\
\hline Marszałek W. & 1995 & $\begin{array}{l}\text { Śladami Krystyny Wituskiej po dawnym } \\
\text { powiecie szadkowskim }\end{array}$ & 3 (39), s. 25-28, il. \\
\hline Nejman E. & 2014 & Lekarze powiatu sieradzkiego $w$ XIX wieku & $2(114)$, s. $23-27$. \\
\hline Nejman E. & 2009 & Powiat szadkowski w dawnej statystyce & $2(94)$, s. $35-39$. \\
\hline Nejman E. & 2008 & $\begin{array}{l}\text { Wilhelm Nencki-dziedzic dóbr Boczki } \\
\text { i Bruss }\end{array}$ & 4 (92), s. 20-21, il. \\
\hline Rosin R. & 2012 & $\begin{array}{l}\text { Zarys dziejów rzemiosła powiatu } \\
\text { sieradzkiego }\end{array}$ & 1 (105), s. 35-42, il. \\
\hline Ruszkowski A. & 1995 & Turysto, zapraszamy do Szadku! & 3 (39), s. 29-35, il \\
\hline Ruszkowski A. & 1991 & Szadek-jedno z najstarszych miast Polski & $1(21)$, s. 29-31, mapka \\
\hline $\begin{array}{l}\text { Kluge M., } \\
\text { Milczarski E. }\end{array}$ & 1992 & Rezerwat „,Wojstawice” & 1 (25), s. 10-11, mapka \\
\hline Urbański M. & 2009 & $\begin{array}{l}\text { Wczesne średniowiecze w okolicach } \\
\text { Sieradza }\end{array}$ & $1(93)$, s. 34-36, il. \\
\hline Lew-Starowicz J. & 1992 & Biografie sieradzkie & $1(25)$, s. $8-10$. \\
\hline Chomętowski W. & 1995 & $\begin{array}{l}\text { Sejmik Szadkowski z } 1788 \text { r., Przedruk } \\
\text { z Pamiętnik hr. Feliksa Eubieńskiego } \\
\text { streścił i opracował..., Warszawa } 1876\end{array}$ & 3 (39), s. 24 , il. \\
\hline Leopold J. & 1987 & $\begin{array}{l}\text { Ziemia Szadkowska w Sieradzkiem. } \\
\text { (Trakt Uniejowski od st. k. ż. Zduńska } \\
\text { Wola do Porczyn), do druku przygotował } \\
\text { Andrzej Ruszkowski }\end{array}$ & $\begin{array}{l}3 \text { (czerwiec-wrzesień), } \\
\text { s. } 20-26, \text { il. }\end{array}$ \\
\hline Stulczewski J. & 2014 & $\begin{array}{l}\text { Przerwana miłość do lasu. Przedwczesna } \\
\text { śmierć Jana Franckiego - leśniczego } \\
\text { Leśnictwa Piaski w Nadleśnictwie Szadek; } \\
\text { oprac. Jarosław Stulczewski }\end{array}$ & $4(116)$, s. 81 \\
\hline Włodarczyk Z. & 2012 & Szadek w leszczyńskim „Przyjacielu Ludu” & $1(105)$, s. $47-49$. \\
\hline Stefańska D. & 1995 & Szadek 1945-1995 & $3(39)$, s. $36-37$. \\
\hline Krajewski J. & 1987 & Zapadlisko [Boczki] & $\begin{array}{c}1 \text { (styczeń-marzec), } \\
\text { s. } 23-24 .\end{array}$ \\
\hline
\end{tabular}

[Wpłynęło: marzec; poprawiono: czerwiec 2016 r.] 


\title{
SZADEK AND ITS REGION IN THE PERIODICAL "NA SIERADZKICH SZLAKACH"
}

\begin{abstract}
Summary
This article presents the thematic scope and time span covered by works dedicated to the town and district of Szadek, published in the journal "Na Sieradzkich Szlakach". A review of the bibliography shows that issues relating to this region have been dealt with in a comprehensive and varied way. The contributions address the history of the town and its economic, cultural and educational development over the centuries. Separate sections of the journal contain bibliographies of outstanding people connected with this region as well as monuments of its material and spiritual past. In line with the profile of the periodical, all these contributions popularise knowledge about the region and encourage visiting this part of the country.
\end{abstract}

Keywords: Szadek, Szadek region, periodical, "Na Sieradzkich Szlakach”. 